\title{
Introduction to geochemistry of metalliferous black shales
}

\author{
Philip A. Meyers ${ }^{\mathrm{a}}$, Lisa M. Pratt ${ }^{\mathrm{b}}$ and Bartholomew Nagy ${ }^{\mathrm{c}}$ \\ ${ }^{a}$ Department of Geological Sciences, The University of Michigan, Ann Arbor, MI 48109, USA \\ ${ }^{b}$ Department of Geological Sciences, Indiana University, Bloomington, IN 47405, USA \\ 'Laboratory of Organic Geochemistry, Department of Geosciences, The University of Arizona, Tucson, AZ 85721, USA
}

(Accepted for publication March 9, 1992)

\section{Metalliferous black shales}

Metalliferous black shales exhibit a wide range of physical and chemical characteristics. They can be enriched in many different metals, and the metals can be in a variety of geochemical states. Depositional and geological histories of these shales are diverse. Some metalliferous black shales contain relatively high concentrations of organic matter whereas others do not. Because of elevated carbonate contents, some are calcareous shales or marlstones. Metal enrichments can result from redox reactions mediated by bacteria during early diagenesis and also from those associated with hydrothermal processes after deep burial. However, unifying characteristics of metalliferous black shales are sufficiently well established to justify combining a diverse number of fine-grained sedimentary rock types under a common term that reflects enhanced metal content, dark color and an inferred association with organic matter (e.g., Huyck, 1990). Moreover, the term "metalliferous black shales" is sufficiently accepted that Working Group 254 of the International Geological Correlation Program (IGCP) has that title and focus. This special issue of Chemical Geology brings together reports describing characteris-

Correspondence to: P.A. Meyers, Department of Geological Sciences, The University of Michigan, Ann Arbor, MI 48109 , USA. tics and considering origins of selected examples of these scientifically interesting and economically important deposits.

\section{Ore formation}

Formation of a metal-rich deposit requires concentration of metallic elements above average crustal levels. Heated water from one or more of several possible origins is typically involved. Metals are dissolved from their source rocks and are transported to a site where deposition occurs, typically by redox-influenced precipitation but sometimes by simple cooling of heated fluids. Continued inflow of a metalbearing solution can result in deposition of relatively large amounts of metalliferous minerals, in some cases enriching the host rocks sufficiently to form an ore deposit. The addition of heat above burial temperature expands the range of geochemical processes that are kinetically possible.

\section{Role of organic matter in ore formation}

Many metallic ore deposits are associated with rock strata having enhanced concentrations of organic carbon, leading to the conclusion that organic matter is involved in some aspect of ore formation (Leventhal, 1986). The nature of this involvement can range from active participation in emplacement of ore deposits to postdepositional alterations of the or- 
ganic matter that are virtually independent of ore-forming processes.

Organic matter can influence ore deposition in numerous ways, all involving oxidation of organic matter. The most commonly postulated role is reduction of metal salts that are carried in solution by hydrothermal waters or hot brines (Anderson and Macqueen, 1982; Hatch et al., 1986; Macqueen, 1986; Püttmann et al., 1988). Soluble metal sulfates can be transported by heated water, and organic matter can reduce these sulfates concomitant with deposition of metal-sulfide minerals. Ore deposits occurring as a native metal can follow from reduction of water-soluble metal cations to an insoluble native element. Again, organic matter can act as the reductant in these processes and become oxidized as a consequence. Incorporation of sulfur into organic matter is possible during the oxidation. However, it is important to note that sulfidation of organic matter can postdate metal deposition and be only indirectly related to the mineralization process. Sulfur incorporation into organic matter after ore formation is exemplified by the Los Ranchos Au deposit at Pueblo Viejo, Dominican Republic (Kettler et al., 1990).

The Kupferschiefer $\mathrm{Cu}-\mathrm{Ag}$ deposit in southwest Poland is a widely cited example of active participation by organic matter in ore formation. Organic substances were oxidized, causing precipitation of metal sulfides, and were thermally degraded, generating gases which created microfractures in an otherwise impermeable rock stratum. Evidence for oxidation of organic matter in the Kupferschiefer includes loss of extractable aliphatic hydrocarbons, sulfidation of aromatic hydrocarbons and decomposition of porphyrins (Püttmann et al., 1988, 1990).

Organic matter can be indirectly involved in formation of metal-rich deposits as a result of oxidation of organic carbon to carbon dioxide during early diagenesis or during later catagenesis. For example, Okita et al. (1988) cite carbon isotopic evidence for deposition of stratiform Mn-carbonate ores, and they postulate that organic matter oxidation occurred during an early stage of diagenesis. Spirakis and Heyl (1988) similarly conclude that Mississippi Valley-type (MVT) deposits can originate from precipitation of carbonates derived from organic carbon during later-stage thermal oxidation. They further suggest that thermal decomposition of organic substance is central to precipitation of fluorite minerals in MVT ores.

Even where organic matter has not directly participated in ore emplacement, the chemical state of ore-associated organic substances can provide information about mineralization processes. Restriction of sulfidized organic matter to areas in the Los Ranchos Formation where all Fe occurs as pyrite suggests that oxidation of ferrous iron was the principal agent in destabilizing Au-bisulfides and precipitating elemental gold at Pueblo Viejo (Kettler et al., 1990). Thermal alteration of organic matter is distinctly zoned around MVT mineral showings in the St. Lawrence Lowlands, Canada, suggesting that hydrothermal fluids provided the additional heat necessary for ore-associated enhancements of regional patterns of burial maturation (Heroux and Tasse, 1990).

\section{Rationale for this special issue}

There is a wide range of possible roles for organic matter in ore deposition that include noninteractive processes during formation of metalliferous deposits. Consideration of both organic and inorganic geochemical factors is especially important. This philosophy led to organization of the symposium entitled "Geochemistry of Metalliferous Black Shales". Speakers were invited to discuss different types of mineralogies and organic matter. The combined theme of organic and inorganic geochemical aspects was fostered by joint sponsorship by the Organic Geochemistry Division of the Geochemical Society and IGCP Working Group 254 . The symposium was held at the 
1990 meeting of the Geological Society of America in Dallas, Texas, U.S.A., and most of the oral presentations are represented as papers included in this special issue. Additional papers were invited to expand and to balance topical coverage in this collection.

The eleven papers in this special issue cover metal-rich deposits ranging in age from modern to Proterozoic. Factors such as the depositional setting, the role of early diagenesis, interactions between metals and mobile fractions of organic matter, and later-stage redox processes are discussed in the context of specific ore bodies. Selected overview papers describe specific categories of mineral deposits. This collection covers both established and emerging views of the processes which participate in forming metalliferous black shales.

\section{Summaries of articles}

The Black Sea is often used as a modern analog for sites of ancient black shale deposition. Lyons and Berner present new evidence about the geochemical interrelationships of carbon, sulfur and iron in the sediments of the Black Sea. Their data show that sulfate reduction proceeds at surprisingly slow rates despite high concentrations of organic carbon. Formation of pyrite is controlled by the availability of $\mathrm{Fe}$ during very early diagenesis. The recent sediment record of the Black Sea is more variable and complicated than usually considered for persistently anoxic bodies of water.

$\mathrm{Au}-\mathrm{Ag}$ deposits in the Cretaceous maardiatreme complex at Pueblo Viejo are an example of complex geochemical processes in mineral deposition. Kettler and colleagues conclude that early diagenetic in situ oxidation of sedimentary organic matter to form framboidal pyrite limited later precipitation of $\mathrm{Au}$. The capacity of sedimentary rocks to consume $\mathrm{H}_{2} \mathrm{~S}$ and thereby precipitate $\mathrm{Au}$ from solution was controlled by the amount of Fe which escaped pyritization and was present as siderite. Early diagenetic reactions in the $\mathrm{C}-\mathrm{S}-\mathrm{Fe}$ sys- tem established the course of later-stage hydrothermal redox reactions.

The several roles for organic matter in formation of the Permian Kupferschiefer $\mathrm{Cu}-\mathrm{Ag}$ sulfide deposits are examined by Jowett. Elevated concentrations of organic carbon in the Kupferschiefer marine black shale created a strong redox gradient between the shale and underlying continental redbeds. Framboidal pyrite was formed in the shales during early diagenesis. Oxidized metal-bearing fluids that migrated upwards into the shale were reduced by both organic matter and Fe-sulfides, precipitating $\mathrm{Cu}$-Ag-sulfides. Thermal decomposition of organic substances produced gaseous hydrocarbons and created microfractures in the rock that enhanced fluid migration.

Changes in intensity of stratification of the water column are inferred to explain variations in metal contents of the Midcontinent Upper Pennsylvanian Stark Shale by Hatch and his colleagues. Large-scale cyclicity in metal and organic carbon concentrations reflects fluctuations in the oxic-anoxic interface in the former epicontinental sea. Low metal concentrations indicate a weakly stratified, dysaerobic water column. High concentrations of $\mathrm{Cd}$, Mo, U, V, Zn, S and organic carbon record periods of anoxia and resulting reducing conditions at the time of sediment accumulation.

Black shales in the North American midcontinent typically display a range of compositions even though they may be of similar geologic ages and closely situated. Schultz and Coveney compare Pennsylvanian black shales from Indiana, Missouri and Kansas and find that degrees of pyritization, metal concentrations and amount of organic carbon reflect differences in bottom-water oxygenation during initial sediment deposition. Nearshore, offshore and lagoonal paleodepositional settings result in formation of distinct types of metalliferous black shales.

Coveney and colleagues consider the possible sources of enrichments of $\mathrm{Ni}, \mathrm{Mo}, \mathrm{Au}$ and platinum group elements (PGE) in Paleozoic 
black shales. Biogenic concentration, hydrothermal epigenesis, volcanic exhalations, lowtemperature emplacement and extraterrestrial origins have been proposed. Migrating fluids of one type or another seem to be the principal agents. Comparison of shale compositions to PGE distributions in meteorites shows that extraterrestrial contributions are unlikely to be important sources of metals to this type of black shale.

Metal enrichments in bitumens from several types of Lower Carboniferous ore deposits in the British Isles are described by Parnell. Metals are present as tiny inclusions that evidently were deposited from hydrothermal fluids soon after or concurrently with hydrocarbon generation and migration. This relationship suggests that a single heating event caused generation of hydrocarbons and mobilization of metals. Emplaced bitumens appear to have played a direct role in precipitating metals.

The role of organic matter in precipitating metals from hydrothermal fluids is further investigated by Monson and Parnell. They describe a variety of metal-organic relationships in Lower Carboniferous deposits in Ireland. Both syngenetic and epigenetic mineralization are evident, and organic matter is associated with both types. Dispersed organic matter, coaly particles and vein bitumens appear to be equally suitable agents for reduction of migrating metal fluids.

Similarities in isotopic and mineralogic compositions between Jurassic stratiform Mncarbonate ores in Mexico and those of Devonian age in China are noted by Okita and Shanks. Although widely separated geographically and temporally, these deposits share a common mode of formation. Mn-carbonates probably precipitated from early diagenetic reduction of $\mathrm{MnO}_{2}$ via bacterial oxidation of organic matter to $\mathrm{CO}_{2}$ in dysaerobic-to-anoxic marine basins.

A correlation between the occurrence of stratiform $\mathrm{Zn}-\mathrm{Pb}$ ores in the geological record and former periods of stratified, anoxic ocean basins is noted by Turner. These deposits occur in Proterozoic, Lower Paleozoic and Jurassic rocks. Stratiform $\mathrm{Zn}-\mathrm{Pb}$ minerals form as hydrothermal sediments associated with submarine venting of metal-rich fluids. Periods of oceanic anoxia may have enhanced the supply of reduced sulfur required to precipitate these deposits.

The Nonesuch Formation was deposited in the Late Proterozoic and was invaded by several migrations of hot, metal-bearing solutions. Mauk and Hieshima consider relationships between native copper, $\mathrm{Cu}$-sulfides and organic matter in the Nonesuch Formation at White Pine Mine and outside the mineralized zone. Formation of pyrite during early diagenesis evidently was important to subsequent deposition of $\mathrm{Cu}$-sulfide. Oxidation of organic matter appears to have aided precipitation of native copper. Emplacement of thermally generated hydrocarbons accompanied secondstage mineralization; these migrated petroleums may have been oxidized during native copper deposition. Comparison of biomarker contents of strata in the mineralized White Pine region with those outside show that passage of hot solutions was confined to the mineralized zone.

\section{Conclusions}

When organic and inorganic geochemical analyses are combined with geological evidence about mineralogy, structural setting and hydrothermal history, a better understanding of metalliferous black shales emerges. Comparisons of mineralized and non-mineralized rocks from the same formations are an important part of this approach. Original depositional settings often establish conditions that dictate subsequent mineralization. Distinguishing between redox pathways that are controlled by bacterial metabolism versus hydrothermal reactions remains a challenging area for future investigation. 


\section{Acknowledgements}

We thank the Joint Technical Program Committee of the 1990 annual meeting of the Geological Society of America for providing the opportunity to arrange the symposium which resulted in this special issue. Moral support and encouragement of the Organic Geochemistry Division of the Geochemical Society and IGCP Working Group 254 are appreciated. We are especially grateful to our technical reviewers: T.F. Anderson, D. Canfield, B. Cecil, J. Clayton, W.E. Dean, G. Desborough, R. Finkelman, H.J. Gluskoter, J.R. Hatch, P. Heckel, J.S. Huebner, H.L.O. Huyck, E.C. Jowett, S.E. Kesler, J. Leventhal, J.L. Mauk, J.B. Maynard, D.M. McKirdy, B.N. Opdyke, R.M. Owen, W. Püttmann and R. Raiswell. These scientists generously gave time and effort to the review process. Their thoughtful comments contribute much to the quality of the papers in this special issue.

\section{References}

Anderson, G.M. and Macqueen, R.W., 1982. Ore deposit models, 6. Mississippi-Valley-type lead-zinc deposits. Geosci. Can., 9: 108-117.

Hatch, J.R., Heyl, A.V. and King, J.D., 1986. Organic geochemistry of hydrothermal alteration, basal shale and limestone beds, Middle Ordovician Quimbys Mill Member, Platteville Formation, Thompson-Temperly zinc-lead mine, Lafayette County, Wisconsin. In: W.E. Dean (Editor), Organics and Ore Deposits. Denver Regional Exploration Society, Denver, Colo., pp. 93104.

Heroux, Y. and Tasse, N., 1990. Organic matter alteration in an early Paleozoic basin: Zonation around mineral showings compared to that around intrusion,
St. Lawrence Lowlands, Quebec, Canada. Geol. Soc. Am. Bull., 102: 877-888.

Huyck, H.L.O., 1990. When is a metalliferous black shale not a black shale? In: R.I. Grauch and H.L.O. Huyck (Editors), Metalliferous Black Shales and Related Ore Deposits - Proceedings, 1989 United States Working Group Meeting, Denver, International Geological Correlation Program Project 254. U.S. Geol. Surv., Circ. 1058, pp. 42-56.

Kettler, R.M., Waldo, G.S., Penner-Hahn, J.E., Meyers, P.A, and Kesler, S.E., 1990. Sulfidation of organic matter associated with gold mineralization, Pueblo Viejo, Dominican Republic. Appl. Geochem., 5: 237248.

Leventhal, J.S., 1986. Roles of organic matter in ore deposits. In: W.E. Dean (Editor), Organics and Ore Deposits. Denver Regional Exploration Society, Denver, Colo., pp. 7-20.

Macqueen, R.W., 1986. Origin of Mississippi Valley-Type lead/zinc ores by organic matter-sulfate reactions: The Pine Point example. In: W.E. Dean (Editor), Organics and Ore Deposits. Denver Regional Exploration Society, Denver, Colo., pp. 151-164.

Macqueen, R.W. and Powell, T.G., 1983. Organic geochemistry of the Pine Point lead-zinc ore field and region, Northwest Territories, Canada. Econ. Geol., 78: $1-25$.

Okita, P.M., Maynard, J.B., Spiker, E.C. and Force, E.C., 1988. Isotopic evidence for organic matter oxidation by manganese reduction in the formation of stratiform manganese carbonate ore. Geochim. Cosmochim. Acta, 52: 2679-2685.

Püttmann, W., Hagemann, H.W., Merz, C. and Speczik, S., 1988. Influences of organic material on mineralization processes in the Permian Kupferschiefer Formation, Poland. Org. Geochem., 13: 357-363.

Püttmann, W., Heppenheimer, H. and Diedel, R., 1990. Accumulations of copper in the Permian Kupferschiefer: A result of post-depositional redox reactions. Org. Geochem., 16: 1145-1156.

Spirakis, C.S. and Heyl, A.V., 1988. Possible effects of thermal degradation of organic matter on carbonate paragenesis and fluorite precipitation in Mississippi Valley-type deposits. Geology, 16: 117-1120. 